\title{
Escayola reforzada con fibras de polipropileno y aligerada con perlas de poliestireno expandido
}

\author{
PPF-reinforced, ESP-lightened gypsum plaster
}

\author{
A. García Santos ${ }^{(*)}$
}

Recepción/Received: 28-III-07

Aceptación/Accepted: 20-IX-07

Publicado online/Online publishing: 2-III-09

\section{RESUMEN}

Se ha obtenido un nuevo material de construcción aditivando el yeso o la escayola, mediante la incorporación de agregados, de modo que sin reducir la resistencia a flexotracción de una escayola sin ningún tipo de adición, reduce su densidad a la mitad, y por tanto, el peso de los elementos constructivos que puedan realizarse basándose en él.

El material está compuesto por una adición de gránulos de poliestireno expandido y fibras cortadas de polipropileno.

El nuevo material incide sobre aquellos aspectos de más interés en el campo de la investigación en construcción, en donde se intenta reducir el peso de los materiales, de modo que se grave lo menos posible la estructura resistente de las edificaciones, a la par que se facilitan los procedimientos de montaje de las unidades constructivas, al poder ser manejadas por un solo operario.

La escayola, con relación de agua / conglomerante de 0,7, y con adiciones del $2 \%$ en peso (sobre la cantidad de escayola), tanto de poliestireno expandido como de fibras de polipropileno, permite reducir la densidad en un $50,88 \%$ sobre los valores de una escayola sin ningún tipo de adición y de un $32,88 \%$ con respecto a las placas de yeso laminado.

Palabras clave: yeso, escayola, aligeramiento, refuerzo de fibras, EPS.
SUMMARY

A new construction material has been obtained by adding aggregate to gypsum plaster which, without reducing the bending strength of plain gypsum plaster without aggregates, lowers its density, and consequently the weight of the construction elements made from the agglomerated material, by half.

The aggregates used were expanded polystyrene beads and short polypropylene fibre.

The new material addresses one of the issues of cardinal interest in construction materials and construction element research, namely the need to lighten materials so as to ease the burden on buildings' bearing structures while facilitating assembly of construction units, by a single worker wherever possible.

With a water / binder ratio of 0.7 and 2\% (by weight of plaster) of expanded polystyrene and $2 \%$ of polypropylene fibre aggregates, the decline in density achieved was $50,88 \%$ over plain gypsum plaster and $32.88 \%$ over plasterboard.

Keywords: gypsum, plaster, lightweight, fibre-reinforcement, EPS.

(*) Universidad Politécnica de Madrid

Persona de contacto/Corresponding author: 


\section{INTRODUCCIÓN}

La investigación analiza la cuantificación de la minoración de densidad, sufrida por una matriz de escayola con agregados, en relación con el resto de propiedades.

El objetivo es reducir las desventajas, debidas al exceso de peso, de los sistemas industrializados existentes basados en matrices de materiales conglomerantes hidráulicos, a través de las siguientes acciones:

- Reducción de costes mediante el aligeramiento de elementos constructivos industrializados, facilitando su manipulación en obra.

- Reducción de peso con el fin de no sobrecargar las estructuras de los edificios.

- Evitar la rotura frágil.

La particularización del objetivo de la investigación consiste en obtener elementos industrializados con nuevas propiedades.

- Aumento de resistencias mecánicas con reducción de sección en paneles.

- Disminución de peso de los elementos industrializados por reducción de la densidad.

- Resolución de la problemática de las juntas entre elementos industrializados, utilizando materiales homogéneos e isótropos en contraposición de los materiales heterogéneos y anisótropos, como es el caso de las placas de yeso laminado (yeso-cartón).

La investigación desarrollada surge de la necesidad de aligerar tanto los elementos como las unidades constructivas, de modo que se penalice lo menos posible su influencia sobre la estructura resistente de las edificaciones, a la par que se faciliten los procedimientos de montaje de las unidades constructivas.

El procedimiento de aligeramiento en los materiales conglomerantes suele basarse en un aumento de la porosidad del material, y, dentro de ésta, la búsqueda se centra en la porosidad no accesible ni comunicada (con el fin de evitar problemas futuros de entumecimiento y de reducción de su durabilidad). Este procedimiento suele conllevar la disminución de los valores resistentes, buscándose siempre un equilibrio difícil de cuantificar, entre el aligeramiento y la reducción de su comportamiento mecánico.

Para evitar esta problemática se recurre a reforzar los materiales, aunque los valores de resistencias mecánicas que se obtienen, se ven limitados por la disminución de la superficie de anclaje de los agregados de refuerzo. Como bien es conocido, el refuerzo de un material compuesto puede lograrse por medio de los métodos siguientes:

\section{INTRODUCTION}

The study quantified the aggregate-mediated decline in density in relation to other relevant properties of a gypsum plaster matrix.

The aim was to reduce the drawbacks involved in the onsite assembly of heavy, industrially produced agglomerated materials by:

- Cutting costs with the use of lighter and therefore more readily manipulated industrialized construction elements.

- Reducing the loads on building structures.

- Preventing brittle failure.

The specific aim of the study was to obtain industrialized elements with new properties:

- Higher mechanical strength and smaller panel sections.

- Lighter weight of industrialized elements due to reduced density.

- Solution of joint-related problems between industrialized elements with the use of uniform and isotropic as opposed to non-uniform and anisotropic materials, such as plasterboard.

The research conducted arose from the need to lighten construction elements and units, easing the burden on buildings' bearing structure while facilitating on-site assembly.

Weight reduction in agglomerated materials is generally achieved by increasing porosity, in particular inaccessible or unconnected porosity (to avoid future swelling and the concomitant decline in durability). Since as a rule this procedure entails a decline in strength, designers seek a balance, always difficult to quantify, between lighter weight and lower mechanical performance.

One of the solutions to this problem is to resort to reinforcement, although the strength values obtained are limited by the decline in the anchorage area of reinforcing aggregates. Composite materials can be reinforced by any of the following methods: 
- Aumento de la superficie de contacto de los agregados cristalinos de la escayola al disminuir la porosidad interna, conllevando un aumento de las resistencias mecánicas y un aumento de peso (5-6).

- Distribución de los agregados fibrosos para posibilitar una especialización de la absorción de tensiones internas, tracción para las fibras y compresión para la matriz de escayola (3-4).

- Optimización de las cantidades de cada agregado sobre la base de un análisis del comportamiento tensión-deformación-plastificación-rotura (2).

De esta manera, es posible usar simultáneamente todos estos métodos para obtener mejores resultados, aunque en esta investigación sólo se han utilizado los dos últimos, intentando aumentar la resistencia del material compuesto.

Por otro lado, la adición de gránulos de poliestireno expandido también se ha estudiado como cargas aligerantes (7).

Este estudio propone la especialización de los agregados que se añaden a los materiales conglomerantes, en la doble faceta de aligeramiento y refuerzo, por lo que se plantea una adición combinada de fibras y granulado, sin necesidad de aumentar la porosidad del material.

La forma de conseguirlo se concreta en los siguientes puntos:

- La utilización de adición de fibra de polipropileno, que produce aumentos en su resistencia a flexión, limitando el riesgo de roturas (6).

- El empleo de adición de gránulos de poliestireno expandido, reduciendo sensiblemente su densidad disminuyendo la resistencia a flexión no más allá de la del yeso sin reforzar.

La adición conjunta logra un material compuesto con una especialización de funciones, compensando el incremento de resistencia obtenido por la adición de fibra con la disminución de resistencia que supone la adición de gránulos de poliestireno expandido, de modo que se consigue disminuir la densidad del compuesto, manteniendo la resistencia del yeso sin adiciones.

Por otro lado los elementos industrializados intentan superar la limitación de resistencias mediante diversos métodos, en relación con su aplicación.

Los campos de aplicación de elementos constructivos basados en yeso o escayola es la siguiente:

- Paredes

- Placas de yeso laminado (yeso-cartón) de tamaño suelo-techo sobre montantes metálicos o trasdosados (espesor $1 \mathrm{~cm}$ ).
- Increasing the contact area of crystalline aggregates included in gypsum plaster with declining internal porosity, which raises both mechanical strength and weight (5-6).

- Distributing fibre aggregates to favour discrete absorption of internal stress: tensile stress by the fibre and compressive stress by the plaster matrix (3-4).

- Optimizing the amounts of each type of aggregate based on an analysis of stress-strain-yield-failure behaviour (2).

All these methods can be used in combination to obtain better results, although this study employed only the latter two to enhance the strength of the composite material.

At the same time, the addition of expanded polystyrene beads as lightening fillers was also studied (7).

The approach adopted in the study was to explore the separate lightening and reinforcement functions of fibre and beads, neither of which entails any increase in porosity, when added to agglomerated materials.

This can be achieved as described below:

- The addition of polypropylene fibre to enhance bending strength and limit the risk of breakage (6).

- The addition of expanded polystyrene beads to perceptibly reduce density without lowering bending strength to below the strength of non-reinforced gypsum plaster.

The addition of the two aggregates yielded a composite material with a division of functions, in which the strength gained with the addition of the fibre offset the decline generated by the inclusion of expanded polystyrene beads. In other words, composite density was reduced while the strength of plain plaster with no aggregates was maintained.

A number of methods are in place to surmount the strength limitations of industrialized elements, depending on the application.

The applications of gypsum plaster-based construction elements are as follows:

- Walls

- Metal-framed or backed floor-to-ceiling plasterboard panes (1 $\mathrm{cm}$ thick). 
- Paneles o bloques de gran formato de yeso (espesores 6 a $10 \mathrm{~cm}$ ). Reforzados y sin reforzar. Aligerados y sin aligerar.

- Paneles de tamaño suelo-techo de yeso (espesores 6 a $10 \mathrm{~cm}$ ). Reforzados y sin reforzar. Aligerados (por componentes y/o alveolos verticales) y sin aligerar.

- Techos: continuos o discontinuos.

En particular la placa de yeso laminado (yeso-cartón) es un material compuesto de carácter no homogéneo y anisótropo. El sistema constructivo en que se fundamenta es, en cierta forma, evolución a construcción en seco del sistema a base de montantes de madera o metálicos, cañizo o metal desplegado y tendido de yeso.

Los paneles de yeso emplean alveolos o adiciones de perlita, vermiculita o corcho para aligerar el peso.

Se propone, por tanto, una adición en masa, con distribución aleatoria, y un coeficiente de forma adaptado a las dimensiones de los elementos constructivos a los que puede dar lugar. Este planteamiento da como consecuencia que el comportamiento del material sea isótropo y homogéneo debido a la distribución aleatoria de los agregados.

En conjunto se logra un material compuesto con una especialización de funciones, compensando el incremento de resistencia por la adición de las fibras de polipropileno con la disminución de resistencia que supone la adición de gránulos de poliestireno expandido, igualando la resistencia del yeso sin adiciones.

No se han encontrado referencias, en la fabricación de elementos industrializados para tabiquerías y falsos techos, del empleo de fibra de polipropileno combinado con gránulos de poliestireno expandido, para reducir peso manteniendo la resistencia mecánica de los elementos industrializados, bien sean placas o paneles.

\section{FUNDAMENTOS TEÓRICOS}

La elección de este tipo de agregados está basada en la utilización de materiales poliméricos que poseen una menor tensión superficial que el resto de los materiales utilizados en construcción y de esta manera garantizan su unión. Los procesos de adherencia están relacionados con la diferencia de tensiones superficiales (1).

La disminución de los valores de tensión superficial de un material está también relacionada con las propiedades polares. La superficie de los materiales poliméricos presenta un valor de fuerza de enlace correspondiente a enlaces del tipo Van der Waals, poseyendo el menor valor de fuerza de enlace en relación con el resto de los materiales. Pero a la vez, y debido a la carga polar que
- Large-scale plaster panels or blocks (6 to $10 \mathrm{~cm}$ thick). Reinforced and non-reinforced. Lightened or standard.

- Floor-to-ceiling plaster panels (6 to $10 \mathrm{~cm}$ thick). Reinforced and non-reinforced. Lightened (with vertical and/or waffled panels) or standard.

- Ceilings: continuous or discontinuous.

Plasterboard, specifically, is a non-uniform, anisotropic composite material. The construction system on which it is based is, in a way, the dry version of applying wet plaster to keys made of wood or metal uprights or laths.

Plaster panels use ESP waffled panels or perlite, vermiculite or cork fillers to reduce weight.

The proposal, then, is to add the aggregate to the wet plaster with a random distribution and a form factor adapted to the dimensions of the construction elements for which the material is to be used. The outcome of this approach is a uniform, isotropic material due to the random distribution of the aggregates.

Overall, the composite material obtained is characterized by a division of functions, in which the strength gained with the addition of the fibre offsets the decline generated by the inclusion of expanded polystyrene beads. In other words, composite density is reduced while the strength of plain plaster with no additives is maintained.

A review of the literature on the manufacture of industrialized elements for partitions and suspended ceilings found no reference to the use of polypropylene fibre in combination with expanded polystyrene beads to reduce weight and maintain the mechanical strength of plasterboard panes or panels.

\section{THEORETICAL FUNDAMENTALS}

The choice of aggregates was based on the fact that polymeric materials exhibit a lower surface tension than other materials used in construction. This guarantees bonding, which is related to differences in surface tension (1).

The decline in surface tension in a material is also related to its polar properties. The bonding force on the surface of polymeric materials, the result of Van der Waals type bonds, is lower than in all other materials. But at the same time, due to the polar charge in Van der Waals forces, these surfaces exert high electrostatic attraction, bringing the aggregate into rapid contact with the other 
las fuerzas de Van der Waals poseen, presentan un altísimo valor de fuerza de atracción electroestática, atrayendo al resto de componentes de los materiales conglomerantes, produciendo un rápido acercamiento de las superficies de lo agregados con el resto de componentes de la matriz conglomerante (5) (6), observándose una disminución de los tiempos de fraguado.

La fuerza de adhesión total del compuesto se debe a las fuerzas de los enlaces secundarios y a los entrelazamientos mecánicos entre las fibras. Las primeras son debidas a las fuerzas polares de tipo electrostático que puedan establecerse entre la matriz y los agregados, mientras que las segundas son debidas al rozamiento o enlace físico producido por irregularidades en las superficies de contacto.

Dado que existe una diferente casuística de tipos de polímeros existentes, cada uno de ellos poseerá una tensión superficial específica que interactuará de diferente modo con las matrices en las que se aplique, con fenómenos de adherencia específicos (2). El objeto de la presente investigación es comprobar los resultados que se obtienen agregando a una matriz de escayola gránulos disgregados de poliestireno expandido y fibras de polipropileno, analizando y observando las modificaciones que producen, fundamentalmente las relacionadas con la disminución de densidad y el mantenimiento de los valores de resistencia mecánica.

\section{ESTUDIO EXPERIMENTAL}

\subsection{Materiales utilizados}

Se ha utilizado como matriz la escayola tipo E-30.

El análisis mineralógico de difracción de rayos $\mathrm{X}$ (DRX) sobre la composición de la escayola obtuvo el siguiente resultado: components of the agglomerated matrix (5) (6) and thereby reducing setting time.

Secondary bonds and mechanical intertwining of the fibres also contribute to the total bonding force of the composite. The former are due to the electrostatic forces that may arise between the matrix and the aggregate, while the latter are the result of friction or the physical bonds arising due to irregularities in the contact surfaces.

Each type of polymer has a specific surface tension that interacts differently with the matrices with which it is mixed, generating specific bonding phenomena (2). The aim of the present study was to analyze and observe the changes taking place (primarily the decline in density and maintenance of the initial mechanical strength values) when expanded polystyrene (EPS) beads and polypropylene fibres were added to a plaster matrix.

\section{EXPERIMENTAL STUDY}

\subsection{Materials}

Type E-30 plaster was used as a matrix.

$X$-ray diffraction (XRD) mineralogical analysis of the plaster yielded the following results:

\begin{tabular}{|c|c|c|}
\hline D: & Dihidrato / Dihydrate Ca $\mathrm{SO}_{4} .2 \mathrm{H}_{2} \mathrm{O} /$ & $0.54 \%$ \\
\hline $\mathrm{E}:$ & Hemihidrato / Hemihydrate $\mathrm{Ca} \mathrm{SO}_{4} .1 / 2 \mathrm{H}_{2} \mathrm{O} /$ & $93.03 \%$ \\
\hline $\mathrm{An}:$ & Anhidrita / Anhydrite $\mathrm{Ca} \mathrm{SO}_{4} /$ & $3.70 \%$ \\
\hline $\mathrm{Cc}:$ & $\mathrm{Ca} \mathrm{CO}_{3}$ & $0.05 \%$ \\
\hline & $\mathrm{Mg} \mathrm{CO}_{3}$ & $0.23 \%$ \\
\hline $\mathrm{S}:$ & $\mathrm{SiO}_{2}$ e insolubles / $\mathrm{SiO}_{2}$ and insoluble substances & $2.11 \%$ \\
\hline
\end{tabular}

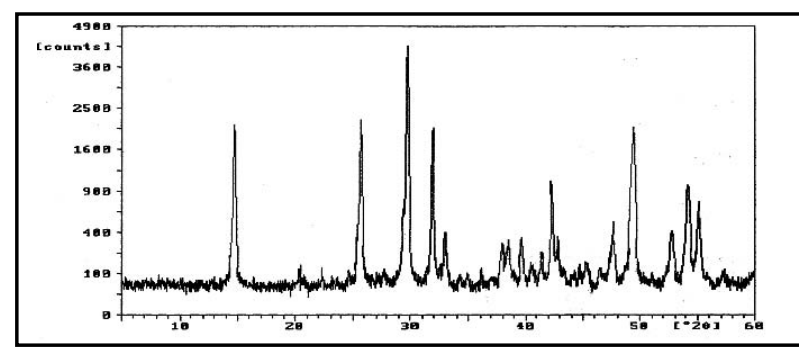

Figura 1. Difracción de rayos $X$ sobre la escayola. Figure 1. X-ray diffractogram for gypsum plaster. 
Este análisis demuestra que la escayola utilizada está compuesta principalmente por semihidrato y cantidades inferiores al $10 \%$ del resto de componentes, así como cantidades de anhidrita del 3,7\%, tal y como se muestra en la Figura 1.

Para la realización de los ensayos se ha utilizado la relación agua / escayola 0,7.

Aligerante: Gránulos de Poliestireno expandido (EPS) Ø $5 \mathrm{~mm}$ completas no procedentes de reciclados (7). Con un rango de adición entre $0-2 \%$.

Refuerzo: Fibra de Polipropileno cortada (FPP) $\varnothing 6$ deniers y longitud $25 \mathrm{~mm}$. Con un rango de adición entre $0-2 \%$.

Se ha seleccionado la fibra de polipropileno por ser polarmente simple, buena resistencia química, resistencia a la fatiga, bajo coste, presentar moléculas de directriz lineal. (1) y haber sido seleccionada en diversas investigaciones anteriormente realizadas en líneas de investigación dirigidas por D. Alfonso García Santos en la Universidad Politécnica de Madrid.

\section{METODOLOGÍA}

Los procedimientos de cuantificación de las propiedades del material se han realizado en el Laboratorio de Materiales de Construcción, del Departamento de Construcción y Tecnología Arquitectónicas, de la Escuela Técnica Superior de Arquitectura de la Universidad Politécnica de Madrid.

Se han aplicado las normas existentes sobre yesos y escayolas, adaptándolas a los materiales compuestos, obteniéndose probetas de $16 \times 4 \times 4 \mathrm{~cm}$, comprobándose posteriormente los resultados con placas de $60 \times 60 \times 1$ $\mathrm{cm}$, de modo que ha permitido obtener conclusiones sobre la influencia del coeficiente de forma en la variación de propiedades $(5,6,12,13)$.

Se ha comprobado experimentalmente la influencia de la adición de granulado disgregado de poliestireno expandido de $5 \mathrm{~mm}$ de diámetro en relación con la adición de fibra cortada de polipropileno de $25 \mathrm{~mm}$ de longitud y 6 deniers (cuya optimización se realizó en anteriores investigaciones) (5).

Se ha realizado un plan de mezclas sobre la matriz de escayola con relación $A / Y$ de 0,7 (13), abarcando rangos entre $0 \%$ y $2 \%$ de adición de cada uno de los agregados seleccionados.

Para comparar los resultados obtenidos y analizar la influencia de las adiciones realizadas, se realizaron unas probetas base de referencia, de escayola sin ningún tipo de adición.
The analysis showed that the plaster used consisted primarily of plaster of Paris, with $3.7 \%$ of anhydrite and small amounts of other components which together accounted for less than $10 \%$ of the total (Figure 1).

The water/plaster ratio used for the trials was 0.7.

Lightener: 0-2\% whole, non-recycled $5 \mathrm{~mm} \varnothing$ EPS beads (7).

Reinforcement: 0-2\% short polypropylene fibre (PPF) $\varnothing$ (25 mm long, 6 denier $\varnothing$ ).

Polypropylene fibre was selected for its polar simplicity, good chemical resistance, fatigue resistance, low cost and the linear configuration of its molecules (1) and because it had been chosen in a number of earlier studies conducted in lines of research headed by Alfonso García Santos at the Polytechnic University of Madrid.

\section{METHODOLOGY}

Material properties were quantified at the Construction Materials Laboratory, Construction and Architectural Technology Department, School of Architecture, Polytechnic University of Madrid.

The existing standards on gypsum plaster were applied and adapted to composite materials. Specimens measuring $16 \times 4 \times 4 \mathrm{~cm}$ were prepared and tested and the results were subsequently verified on $60 \times 60 \times 1-\mathrm{cm}$ panes to determine the effect of the form factor on variations in material properties $(5,6,12,13)$.

Experiments were designed and performed to determine the effect of adding 5-mm diameter ESP beads in combination with short 25-mm, 6 denier $\Delta$ polypropylene fibre (optimized in earlier studies) (5).

Varying amounts of each aggregate, ranging from 0 to $2 \%$, were mixed with the gypsum plaster, using a W/P ratio of 0.7 (13).

Control specimens consisting of gypsum plaster only were also prepared to compare the results obtained and analyze the effect of the aggregates. 


\section{Normativa}

Los ensayos de resistencia mecánica se han realizado de acuerdo con la Normas UNE 102.031 Yesos y Escayolas de Construcción. Métodos de Ensayos Físicos y Mecánicos, y a la Norma UNE 102.032 Yesos y Escayolas de Construcción. Métodos de Análisis Químico.

Se realizaron probetas prismáticas de $16 \times 4 \times 4 \mathrm{~cm}$ en moldes metálicos normalizados con diferentes porcentajes de adición de fibras de polipropileno y de éstas con granulado de poliestireno expandido.

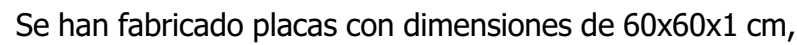
sometiéndose a un ensayo de flexión, en máquina de ensayos con una separación entre apoyos de $40 \mathrm{~cm}$. Para la realización del ensayo se colocó la placa sobre ellos, equidistante del centro y nivelada, sobre la que se colocó un traductor (medidor de deformaciones) en contacto con la placa. El ensayo se realizó a una velocidad de la máquina en $0,4 \mathrm{~mm} / \mathrm{seg}$.

Las características de la célula de carga utilizada son las siguientes:

- carga máxima $2000 \mathrm{kp}$

- tolerancia $<+/-0,2 \%$

- sensibilidad $+1-4 \mathrm{kp}$

\section{RESULTADOS Y DISCUSIÓN}

\subsection{Resultados obtenidos con probetas}

Se analizan los resultados obtenidos en laboratorio, en primer lugar sobre probetas prismáticas normalizadas, que posteriormente se comprueban sobre placas de pequeño espesor de acuerdo a las dimensiones mencionadas. Se hace especial hincapié en la resistencia a flexotracción, ya que es la que determina, en el caso de los derivados del yeso o escayola, las posibles dimensiones o parámetros de dimensionamiento de los elementos constructivos. Posteriormente se comprueba la disminución de densidad que conllevan las adiciones, y el resto de parámetros que se han considerado en el desarrollo de esta investigación.

En la Figura 2 se relacionan los valores de resistencia a flexotracción obtenidos sobre probetas prismáticas de $16 \times 4 \times 4 \mathrm{~cm}$, en donde se observa la influencia unitaria de cada agregado.

El incremento de porcentaje de fibras de polipropileno conlleva el incremento de resistencia mecánica a flexotracción, mientras que la adición de granulado de poliestireno expandido produce una disminución de los valores resistentes.

\section{Standards used}

Mechanical strength tests were performed to the specifications laid down in Spanish standards UNE 102031 (Gypsum plaster for construction. Physical and mechanical test methods) and 102032 (Gypsum plaster for construction. Chemical analysis methods).

Prismatic specimens measuring $16 \times 4 \times 4 \mathrm{~cm}$ were prepared in standardized metallic moulds with different percentages of PPF and EPS beads.

Panes measuring $60 \times 60 \times 1 \mathrm{~cm}$ were made and subjected to a bending test in a load frame with a 40-cm space between supports. In these tests, a transducer (strain meter) was attached to the pane, which was centred and levelled over the supports. The trials were conducted at a machine speed of $0,4 \mathrm{~mm} / \mathrm{s}$.

The characteristics of the load cell used were:

- maximum load: $2000 \mathrm{kp}$

- tolerance: < + $0.2 \%$

- precision: $+1-4 \mathrm{kp}$

\section{RESULTS AND DISCUSSION}

\subsection{Specimens}

The laboratory results obtained with the standard prismatic specimens were first analyzed and subsequently verified on the thin panes described above. Attention was focused on bending strength in particular, for this is the parameter that determines the possible dimensions of plaster-based construction elements. In subsequent steps, the aggregate-induced decline in density and other parameters considered in this study were verified.

The individual effect of each aggregate can be deduced from the bending strength values obtained for the $16 \times 4 \times 4-\mathrm{cm}$ prismatic specimens given in Figure 2.

Bending strength grew with increasing percentages of PPF, whereas the addition of EPS beads led to a decline in strength values. 


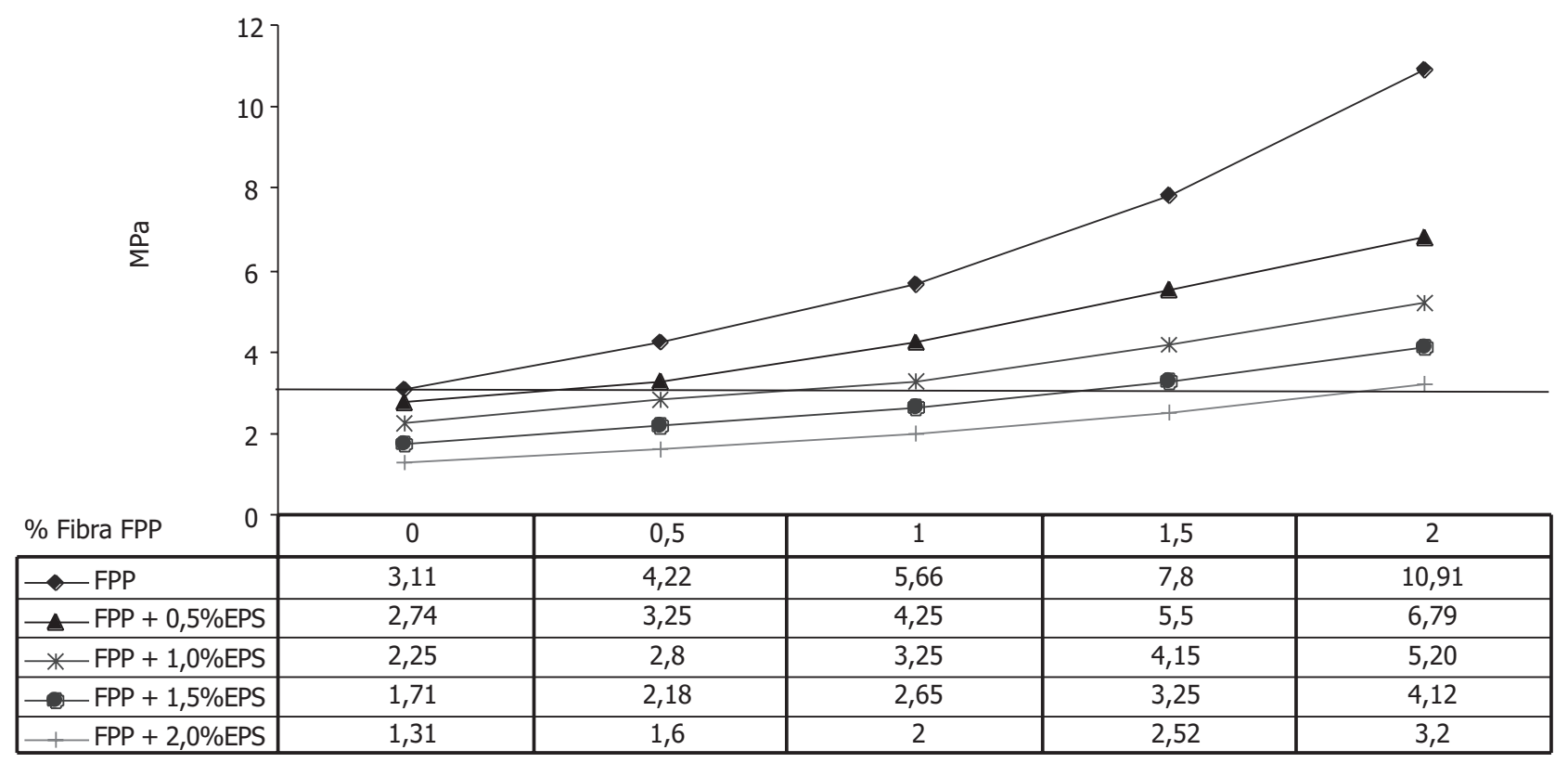

Figura 2. Ensayo de flexotracción.

Figure 2. Bending test.

En la Figura 2 se grafía en una línea horizontal el valor de referencia correspondiente a una escayola sin ningún tipo de adición.

Se observa que los siguientes porcentajes (0\%-0\%) $(0,5 \%-0,5 \%)(1 \%-1 \%)(1,5 \%-1,5 \%)$ y $(2 \%-2 \%)$ (entre granulado de poliestireno expandido y fibras cortadas de polipropileno) se corresponden con pequeños incrementos porcentuales de resistencia, de modo que prácticamente se puede concluir que si se quiere mantener constante el valor de la resistencia a flexotracción de una escayola sin ningún tipo de adición, puede elegirse cualquiera de los citados porcentajes, ya que entre ellos poseen una resistencia similar, entre 3,20 y 3,25 $\mathrm{MPa}$.

Con el fin de visualizar de un modo más inmediato la influencia de las diferentes adiciones ensayadas, en la Figura 3 se especifican los valores obtenidos en la Figura 2 convertidos en porcentajes de incremento de resistencia a flexión, con respecto a los valores obtenidos en las probetas de la escayola sin ningún tipo de adición.

En probetas de $16 \times 4 \times 4$ ensayadas, se observa la distribución y diversas orientaciones de las líneas de rotura, (Figura 4) que demuestran el buen comportamiento conjunto de la matriz con los agregados. Se observan algunas líneas de rotura entre el apoyo superior y el inferior derecho de la probeta. La existencia de varias microfisuras permite que cada una de ellas absorba parte del estado tensional evitando la acumulación de tensiones en un único plano de rotura, con la consiguiente rotura en dos partes de la probeta.
The horizontal line in Figure 2 represents the strength value found for the control, a gypsum plaster specimen with no aggregates added.

Small rises in strength were observed for the following percentage combinations: (0\%-0\%) (0.5\%-0.5\%) (1\%$1 \%)(1.5 \%-1.5 \%)$ and (2\%-2\%), (EPS beads and short PPF). The findings show that regardless of the percentage chosen, the bending strength of the resulting plaster ranged from 3.20 to $3.25 \mathrm{MPa}$, i.e., essentially the same value as found for gypsum plaster with no aggregates.

To visualize the effect of the aggregates tested, the values given in Figure 2 were converted in Figure 3 to the percentage increase in bending strength compared to the control.

The distribution and varied orientation of the failure lines in the $16 \times 4 \times 4-\mathrm{cm}$ specimens (Figure 4) were an indication of the good joint reaction of matrix and aggregates. Several failure lines were found on the specimens between the upper and lower right supports. With several microfissures present, each could absorb part of the stress state, thereby avoiding specimen fracture due to the accumulation of stress on any single failure plane. 


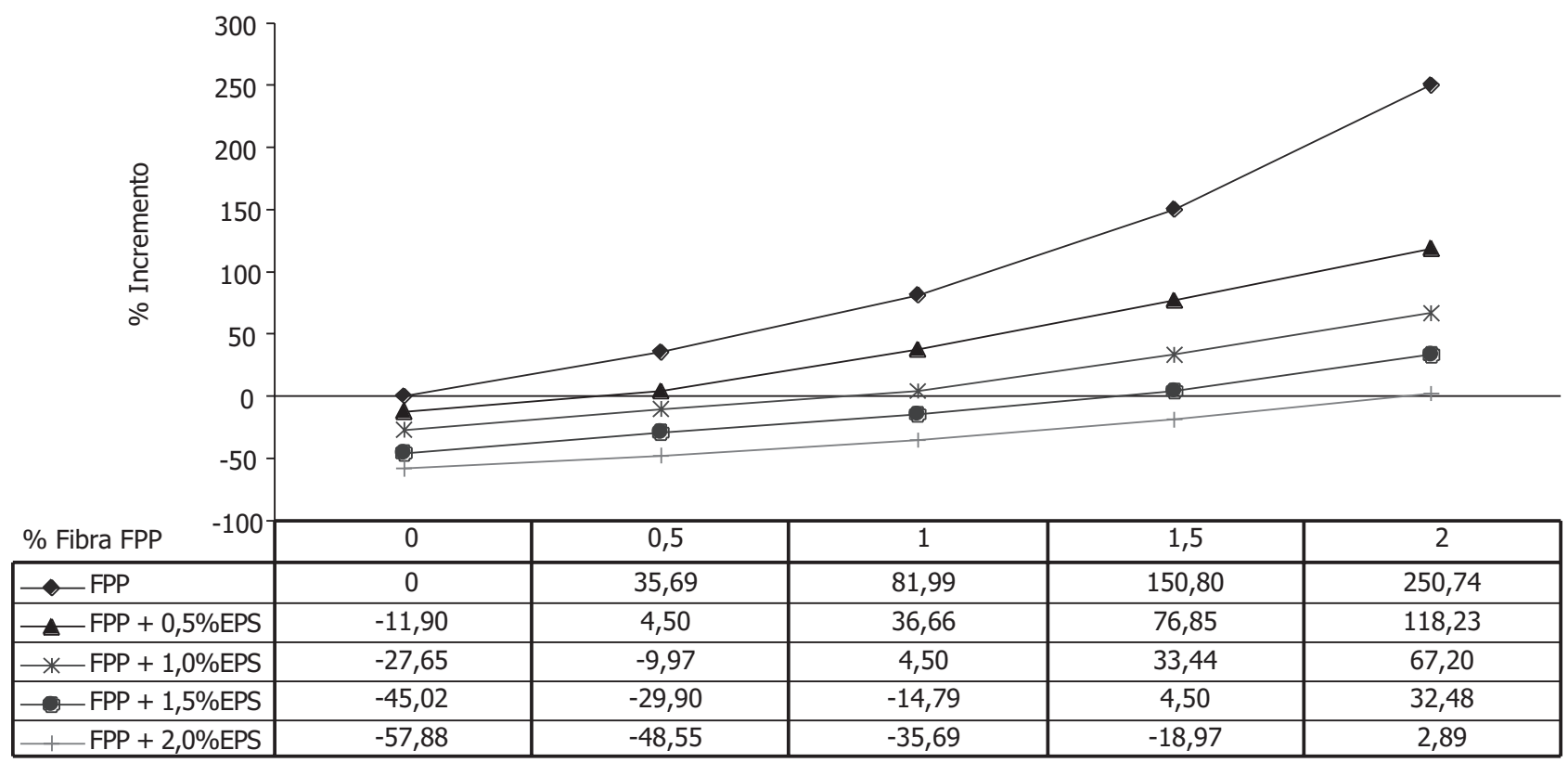

Figura 3. Ensayo de flexotracción. Valores porcentuales con respecto a la escayola sin ningún tipo de adición. Figure 3. Bending test. Percentage of the control value.

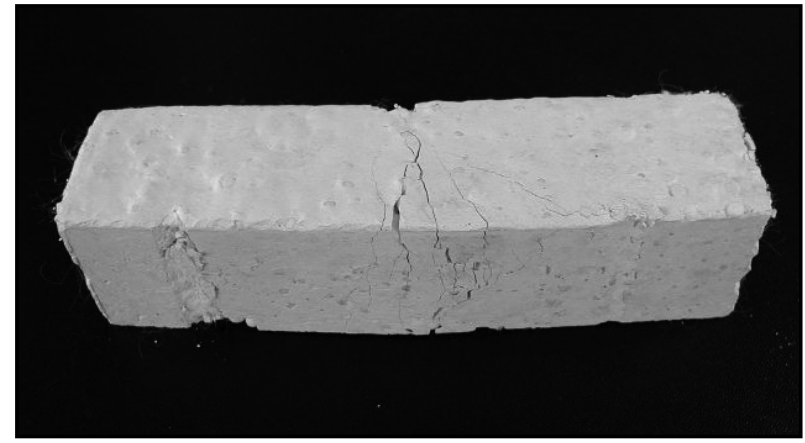

Figura 4. Líneas de rotura en probetas de $16 \times 4 \times 4$. Figure 4. Failure lines on $16 \times 4 \times 4-\mathrm{cm}$ specimens.

Este comportamiento se comprueba también en las adherencias que se observan entre las abundantes cristalizaciones de dihidrato en la superficie de las fibras (Figura 5) (5).
The same behaviour was observed in the bonds between the many dehydrate clusters crystallizing on the surface of the fibres (Figure 5) (5).

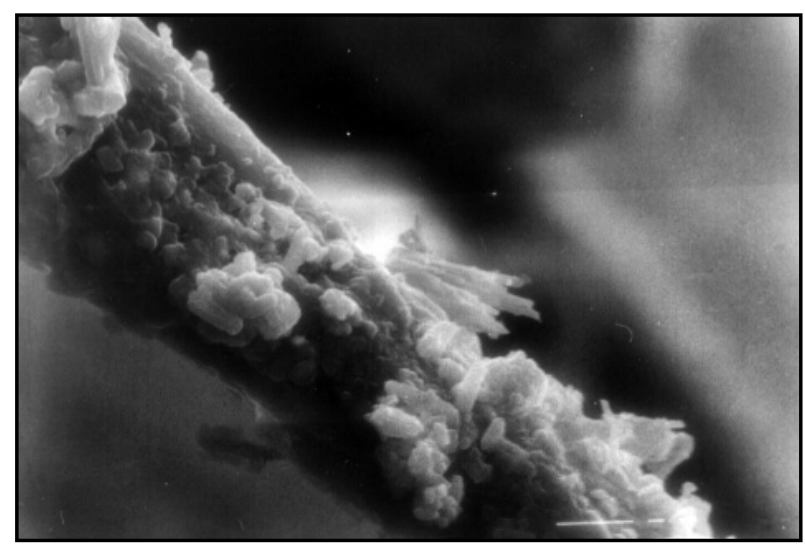

Figura 5. Cristalizaciones de dihidrato en la superficie de las fibras. Figure 5. Dehydrate crystallizing on fibre surfaces. 
En la Figura 6 se relacionan los valores de resistencia a compresión obtenidos sobre probetas prismáticas de $16 \times 4 \times 4 \mathrm{~cm}$, en donde se observa la influencia unitaria de cada agregado.

En la Tabla 3 se grafía en una línea horizontal el valor de referencia correspondiente a una escayola sin ningún tipo de adición.

El incremento de porcentaje de fibras de polipropileno conlleva una disminución de valores de resistencia a compresión. Cuando además de la fibra de polipropileno, se adiciona poliestireno expandido se observa un pequeño incremento de resistencia mecánica a compresión en relación con el incremento de porcentaje de adición de fibra. La adición de granulado de poliestireno expandido produce globalmente una disminución de los valores resistentes.

Esta disminución de valores resistentes ante esfuerzos de compresión produce que se equiparen las resistencias a las obtenidas en el ensayo de flexión, en porcentajes de adición próximos al 1,5\% (tanto de fibras de polipropileno como de EPS), con valores de 3,3 MPa obtenidos en el ensayo de compresión y 3,25 MPa obtenidos en el ensayo de flexión.
The individual effect of each aggregate can be deduced from the compressive strength values obtained for $16 \times 4 \times 4-\mathrm{cm}$ prismatic specimens given in Figure 6.

The horizontal line in Table 3 represents the value found for the control, a gypsum plaster specimen with no aggregates added.

Compressive strength declined with increasing PPF percentages. When ESP was added in conjunction with PPF, compressive strength was observed to rise slightly with rising percentages of fibre. Nonetheless, the addition of ESP beads caused an overall decline in strength values.

For PPF and EPS percentages of around $1.5 \%$, this decline in compressive strength led to values comparable to the bending strength findings, for under these conditions, compressive strength was 3.3 MPa and bending strength 3.25 MPa.

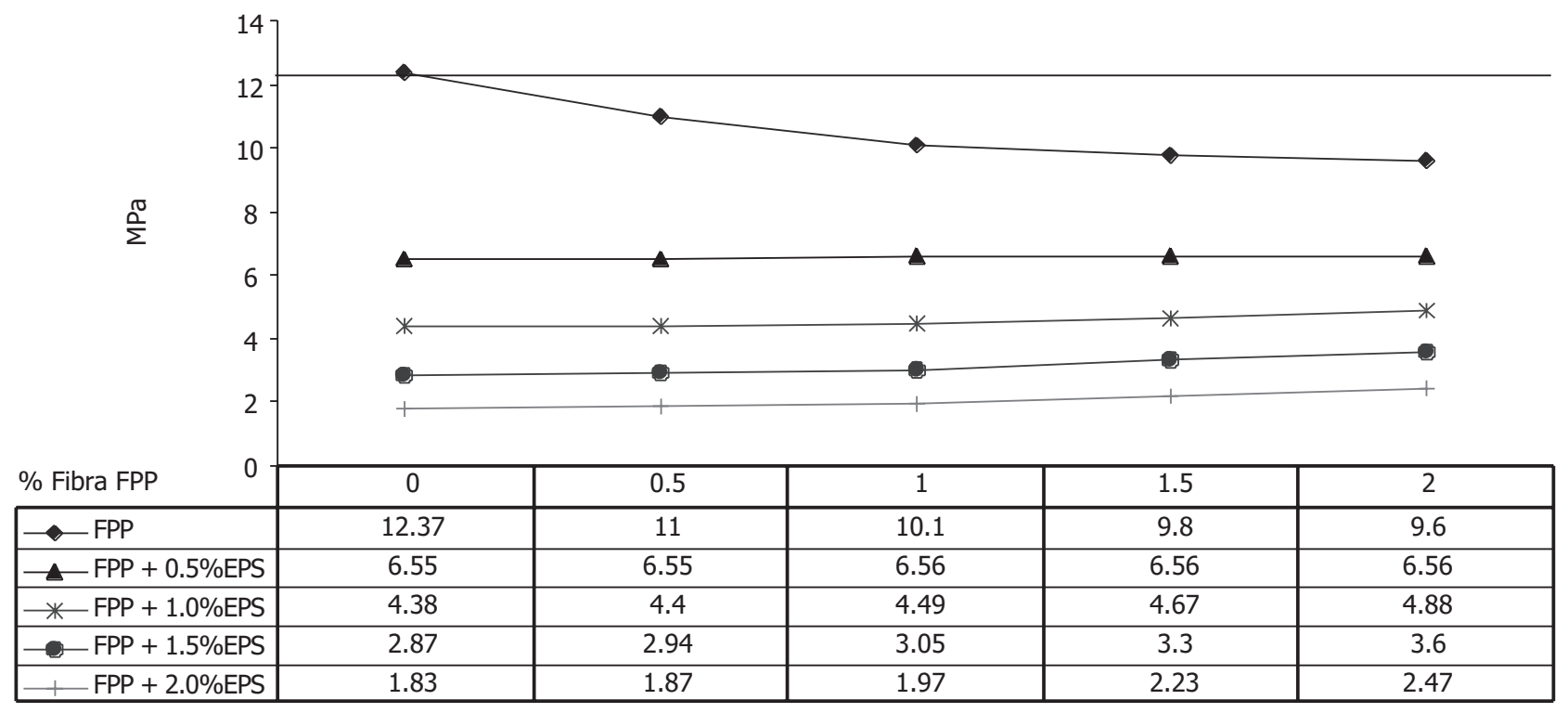

Figura 6. Ensayo de compresión.

Figure 6. Compression test results.

Las propiedades físicas analizadas son la densidad y la porosidad.

En primer lugar se analizan los resultados obtenidos por disminución de los valores correspondientes a las disminuciones de la densidad, debido a la importancia del peso sobre los elementos constructivos: ligereza y facilidad de montaje. Las densidades especificadas se corresponden con probetas secas.
The physical properties analyzed were density and porosity.

Firstly, the declining values attributable to declining density were analyzed, in light of the importance of weight in construction elements and the convenience of assembly afforded by lightweight products. The densities specified refer to dry specimens. 


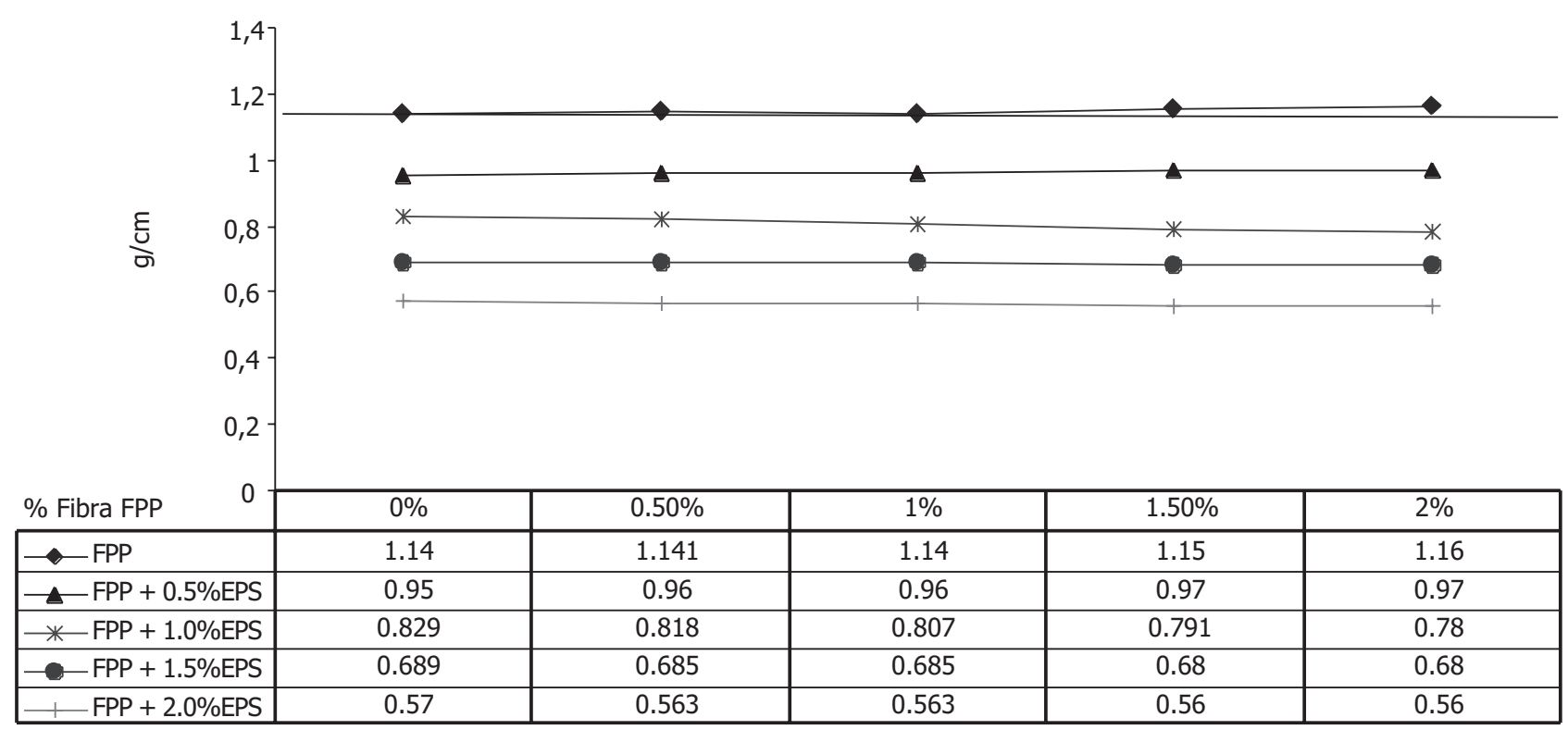

Figura 7. Densidades.

Figure 7. Density.

En la Figura 7 se grafía en una línea horizontal el valor de referencia correspondiente a una escayola sin ningún tipo de adición.

La densidad se ve afectada de un modo importante por las adiciones de poliestireno expandido, que puede ser observado, en valores absolutos, en la Figura $7 \mathrm{y}$, en valores porcentuales, en la Figura 8, con respecto a los obtenidos en la escayola sin ningún tipo de adición. Comprobándose que se obtienen reducciones de la densidad del $50,88 \%$.
The horizontal line plotted in Figure 7 represents the value found for the control, a gypsum plaster specimen with no aggregates added.

Density was greatly affected by the EPS, as shown by the absolute values in Figure 7 and the percentages of the results observed for the control given in Figure 8. Density declined by up to $50.88 \%$.

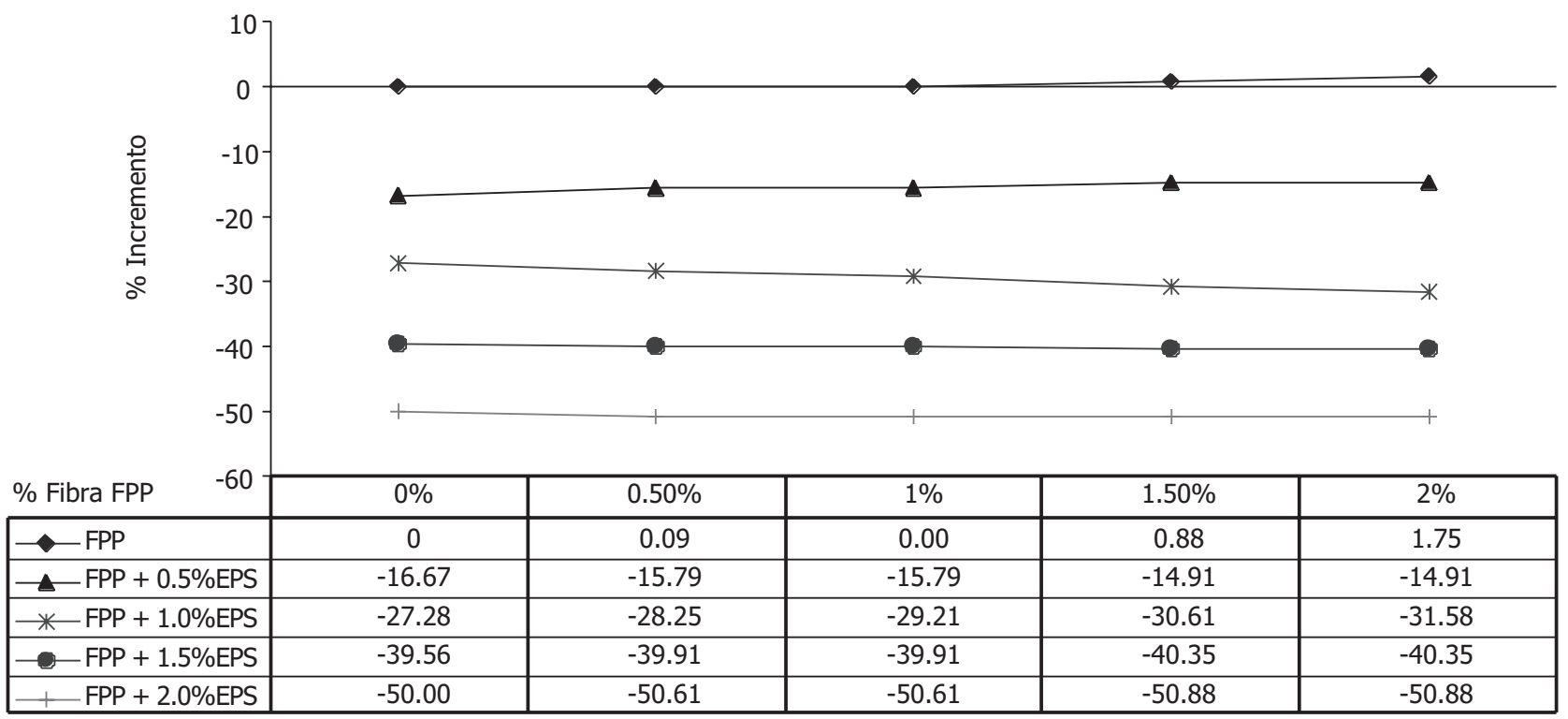

Figura 8. Densidades. Valores porcentuales con respecto a la escayola sin ningún tipo de adición. Figure 8. Density. Percentage of the control value. 
La porosidad no se ve afectada por las adiciones de poliestireno expandido, manteniéndose en rangos de valores que pueden considerarse constantes dependiendo de la relación agua / escayola, sin embargo, los incrementos de adición de fibras de polipropileno reducen la porosidad, como queda reflejado en la Tabla 1.
Porosity was not affected by EPS, and remained in what can be regarded to be a constant range, depending on the water/plaster ratio. Adding PPF reduced porosity, however, as Table 6 shows.

Tabla 1. Coeficiente de absorción y porosidad.

Table 1. Absorption coefficient and porosity.

\begin{tabular}{|c|c|c|}
\hline & Coeficiente de absorción \% / Absorption coefficient \% & Porosidad \% / Porosity \% \\
\hline E-30 & 43.20 & 50.00 \\
\hline E-30 + FPP 2\% & 40.80 & 44.90 \\
\hline
\end{tabular}

Si comprobamos los valores de las adiciones combinadas de análoga resistencia ante esfuerzos de flexotracción con los obtenidos en los ensayos de densidad se obtienen los siguientes resultados.
The aggregate combinations that yielded similar bending strengths are compared to the density test results in Table 2.

Tabla 2. Comparación entre valores de resistencia a flexión y disminución de densidad. Table 2. Comparison of bending strength and density reduction.

\begin{tabular}{|c|c|c|c|c|c|}
\hline FPP \% adición / PPF (\% added) & 0 & 0.5 & 1.0 & 1.5 & 2.0 \\
\hline EPS \% adición / EPS (\% added) & 0 & 0.5 & 1.0 & 1.5 & 2.0 \\
\hline \multicolumn{6}{|l|}{} \\
\hline \% de flexión. MPa / $\sigma$ Bending s (MPa) & 3.11 & 3.25 & 3.25 & 3.25 & 3.2 \\
\hline \% de reducción de densidad / Density reduction (\%) & 0 & -15.79 & -29.21 & -40.35 & -50.88 \\
\hline
\end{tabular}

En la Tabla 2 se puede observar que los valores de resistencia a flexotracción son análogos para los siguientes porcentajes de adición combinada entre fibras y poliestireno expandido (0\%-0\%), (0,5\%-0,5\%), (1\%-1\%), $(1,5 \%-1,5 \%)$ y $(2 \%-2 \%)$. De entre todas las adiciones combinadas se observa que la adición combinada del $2 \%$ para ambos agregados es la que posee mayor reducción de densidad $(50,88 \%)$ para una tensión de flexotracción del orden de 3,2 MPa, superior a los 3,11 MPa obtenidos por una escayola sin ningún tipo de adición.

Estas adiciones no modifican las propiedades superficiales que posee el yeso o la escayola una vez hidratados, ni las de aquellos elementos constructivos que puedan obtenerse basado en ellos.

Las texturas que pueden obtenerse son análogas a las de cualquier producto realizado con escayola sin ningún tipo de adición, ya que en la interfase entre el molde y el material que confina, se producen fenómenos de repulsión de las adiciones de fibras y granulados, de modo que en la superficie del material, una vez desmoldado, no aparecen restos de las adiciones que posee.

Análogamente los valores correspondientes a la dureza Shore $\mathrm{C}$ presentan resultados análogos a los de la escayola sin ningún tipo de adición.
Table 2 shows that bending strength was similar for the following combinations of fibre and EPS: (0\%-0\%), $(0.5 \%-0.5 \%),(1 \%-1 \%),(1.5 \%-1.5 \%)$ and $(2 \%-2 \%)$. Of all these combinations, the mix containing $2 \%$ of both aggregates exhibited the steepest reduction in density (50.88\%) for a bending strength on the order of 3.2 $\mathrm{MPa}$, which was higher than the 3.11 MPa obtained for the plain plaster.

These aggregates did not modify the surface properties of the gypsum plaster after hydration, nor of the resulting construction elements.

The textures obtained were comparable to those of any plain plaster product, for the fibres and beads generated repulsion at the interface between the mould and the material. As a result, no trace of the aggregates appeared on the demoulded elements.

Similarly, the Shore $C$ hardness values found were comparable to the values for plain plaster. 


\section{COMPARACIÓN DE RESULTADOS DE RESISTENCIA A FLEXIÓN, ENTRE PROBETAS Y PLACAS}

Con el fin de comprobar la idoneidad del compuesto para la fabricación de placas (por ser un elemento constructivo de mayor esbeltez y, por tanto, más problemáticos que los paneles), se comparan los resultados obtenidos en el proceso experimental en probetas normalizadas de $16 * 4 * 4 \mathrm{~cm}$, con los obtenidos con placas de $60 * 60 * 1$ $\mathrm{cm}$, concluyéndose que:

- Las densidades obtenidas son análogas con independencia de la forma del elemento ensayado.

- La porosidad es también independiente de la forma de las piezas de ensayo.

- Las resistencias a compresión obtenidas son igualmente análogas.

- Las resistencias obtenidas en los ensayos de flexión presentan importantes diferencias, que pueden observarse en la Figura 9.

Cada uno de los porcentajes reflejados en la Tabla 8 se obtienen por comparación entre los valores obtenidos para cada porcentaje de adición de los agregados, entre los obtenidos en el ensayo de flexión con probetas prismáticas normalizadas y los obtenidos con placas.

En la Figura 9 se observa la influencia de las fibras en los aumentos de resistencia de las placas, a la vez que se observan los porcentajes de disminución de resistencia

\section{COMPARISON OF SPECIMEN AND PANE BENDING STRENGTH}

The suitability of the composite material for pane manufacture (a more slender and therefore more problematic construction element than panels) was analyzed by comparing the findings for standard $16 * 4 * 4-\mathrm{cm}$ specimens to the findings for $60 * 60 * 1-\mathrm{cm}$ panes. The conclusions drawn were:

- The density values were comparable regardless of the shape of the element tested.

- Porosity was likewise independent of the shape of the test pieces.

- Compressive strength values were also similar.

- The bending strengths differed substantially, as shown in Figure 9.

The percentages given in Figure 9 are the result of comparing the prismatic specimen bending strength values to the pane values for each percentage of aggregate added.

The table shows that the fibre aggregate raised pane strength and that smaller strength values were found for the panes than for the prismatic specimens, a result of

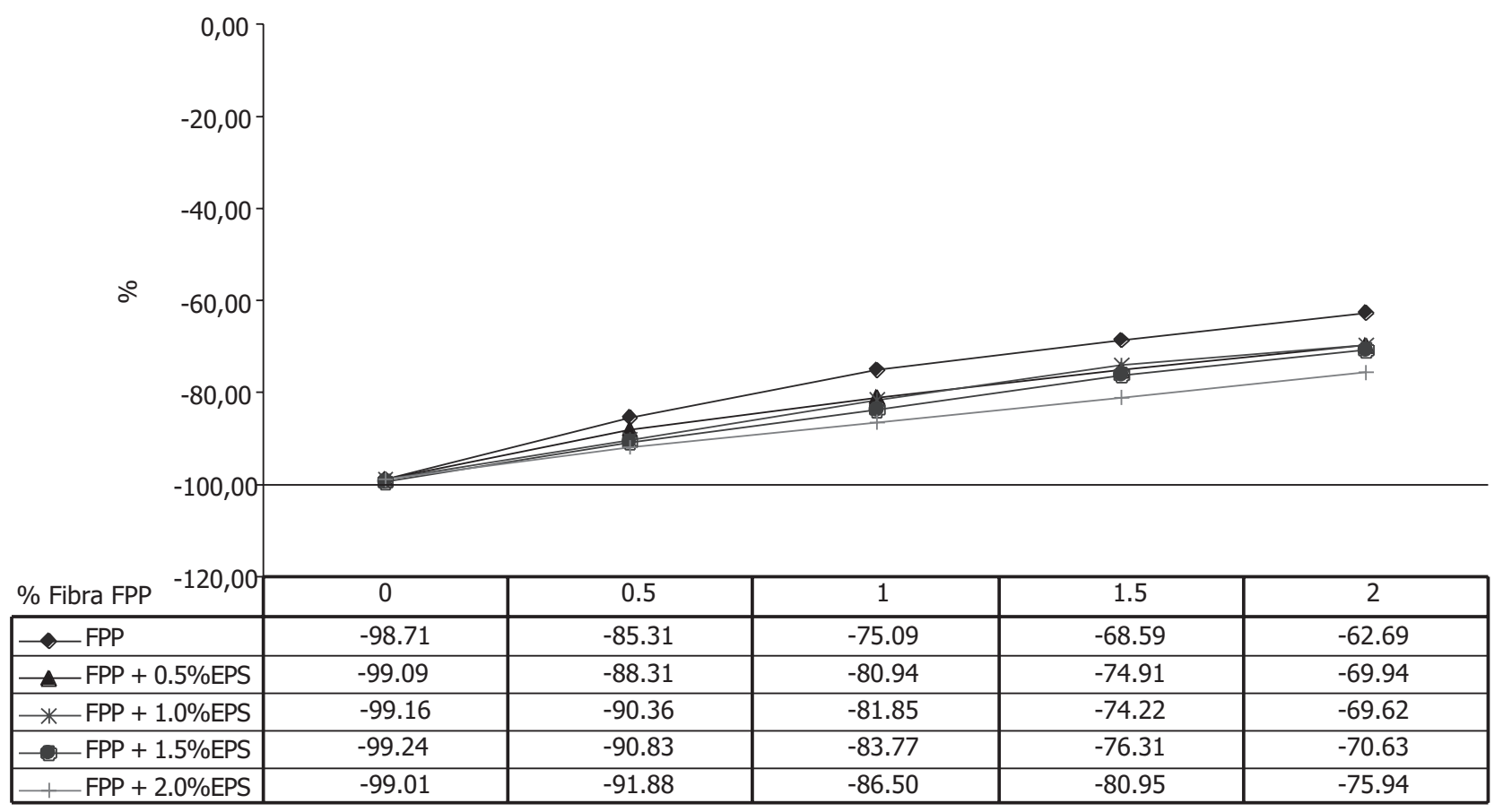

Figura 9. Comparación entre valores de resistencia a flexión entre probetas y placas.

Figure 9. Comparison of specimen and pane bending strength. 
con respecto a las probetas prismáticas, debido a la utilización de placas de tan reducido espesor en relación con las probetas prismáticas. En la misma Figura 9 se grafía en una línea horizontal el valor de referencia correspondiente a una placa realizada con escayola sin ningún tipo de adición.

En la Figura 10 se determinan los porcentajes de incremento de tensiones de rotura de las placas sometidas a ensayo de flexión con respecto a los valores obtenidos en placas de escayola sin ningún tipo de adición. En la misma Tabla se observa que la adición combinada, del $2 \%$ de fibras de polipropileno con el $2 \%$ de EPS, incrementa la resistencia a flexión de las placas en un $22,77 \%$ con respecto a una placa de escayola sin ningún tipo de adición, porcentaje muy superior al 2,89\% de incremento obtenido en las probetas prismáticas y reflejado en la Figura 3. the substantially different thicknesses of the two types of elements. The horizontal line plotted in Figure 9 represents the value found for the control, a gypsum plaster pane with no aggregates added.

Figure 10 gives the increase in bending failure stress for panes as a percentage of the values obtained for plain plaster with no aggregate. The same table shows that the combination of $2 \%$ fibre and $2 \%$ EPS raised pane bending strength by $22.77 \%$ over the value found for a plain plaster pane, i.e., much more than the $2.89 \%$ increase observed for the prismatic specimens, shown in Figure 3.

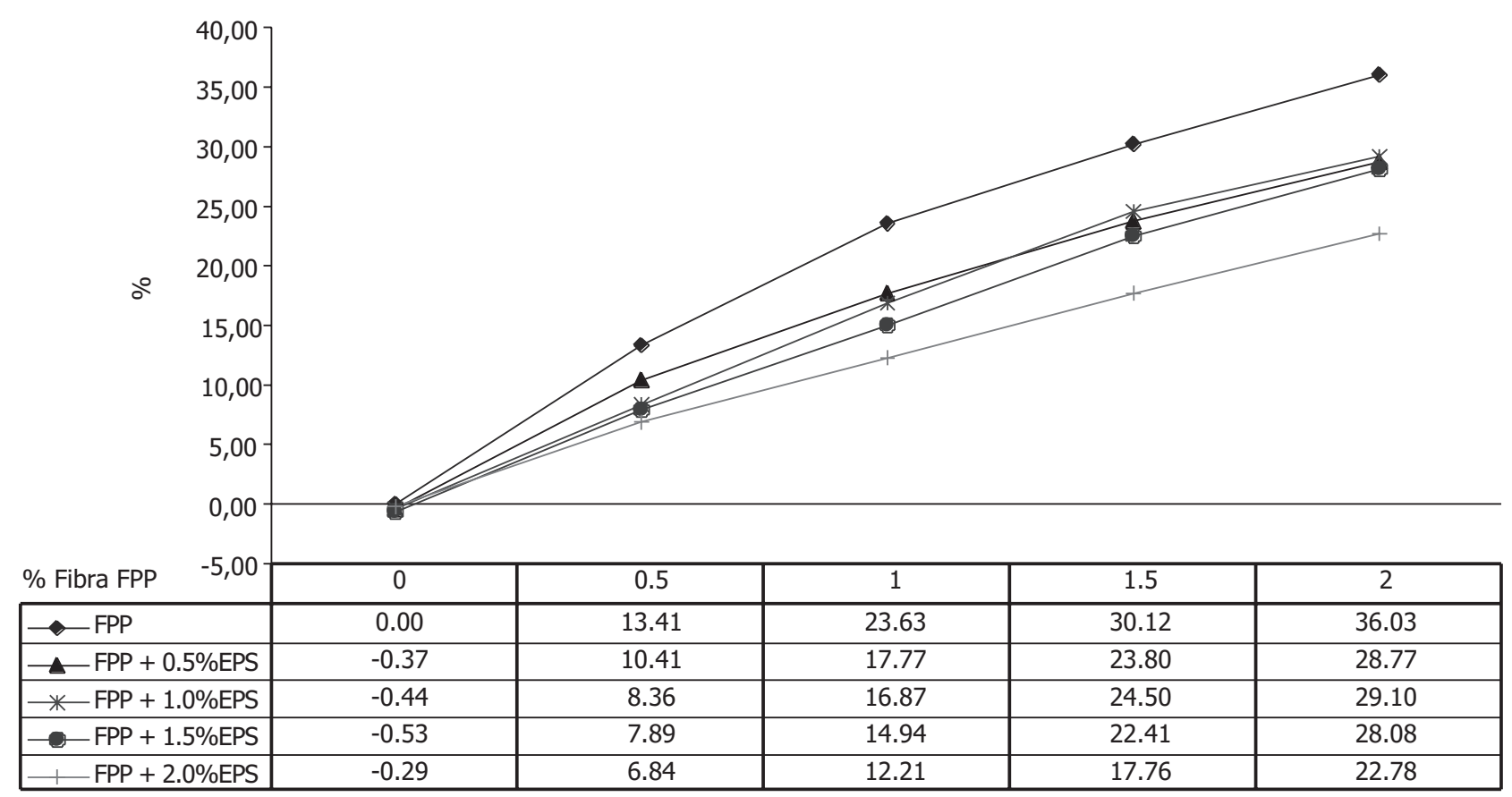

Figura 10. Placas. Valores porcentuales con respecto a placas de escayola sin ningún tipo de adición. Figure 10. Pane bending strength. Percentage of the control value.

En la Figura 11 se representan las gráficas tensión-desplazamiento ante ensayo de flexión de placas, en la que se observa que las placas reforzadas con fibras de polipropileno y aligeradas con EPS presentan una gran tenacidad, como consecuencia de la deformabilidad, evitando la rotura frágil de las placas.

En la gráfica se observa el periodo elástico correspondiente a la matriz de escayola, a partir del cual el material se comporta de modo plástico, manteniendo valores de resistencia casi constantes ante importantes deformaciones.
The bending stress-strain curves for panes in Figure 11 show that the panes reinforced with PPF and lightened with EPS were very tough. Their resulting deformability prevented brittle failure in the material.

Note that after the yield strength was reached, the material maintained its plasticity, with nearly constant strength values, under very high strain. 


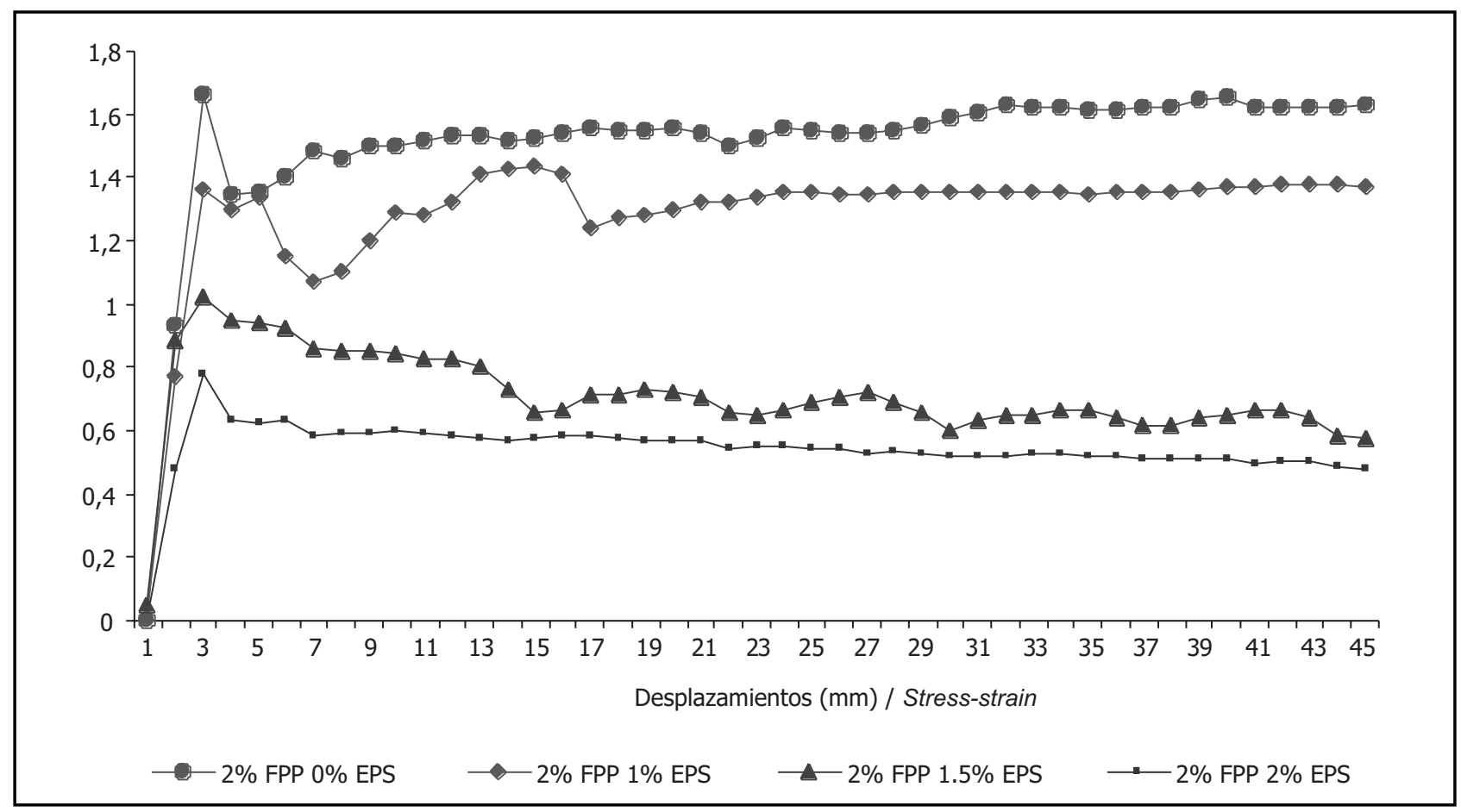

Figura 11. Ensayo de flexión de placas de 60×60×1 cm. Gráficas de tensión-desplazamiento.

Figure 11. Bending test on 60x60x1-cm panes. Stress-strain diagrams.

Se han limitado en el ensayo los desplazamientos a 45 $\mathrm{mm}$, debido a las características de la máquina de ensayo, aunque se han llegado a obtener flechas de 1/30 de la distancia de apoyos.

En las placas ensayadas (Figura 12) se observa la distribución y diversas orientaciones de las líneas de rotura, que demuestran el buen comportamiento conjunto de la
Due to the characteristics of the load frame, the test was limited to a strain of $45 \mathrm{~mm}$, although deflection values of up to $1 / 30$ of the distance between supports were obtained.

As in the $16 \times 4 \times 4-\mathrm{cm}$ specimens (Figure 12), the distribution and varied orientation of the failure lines in the panes were an indication of the good joint reaction of
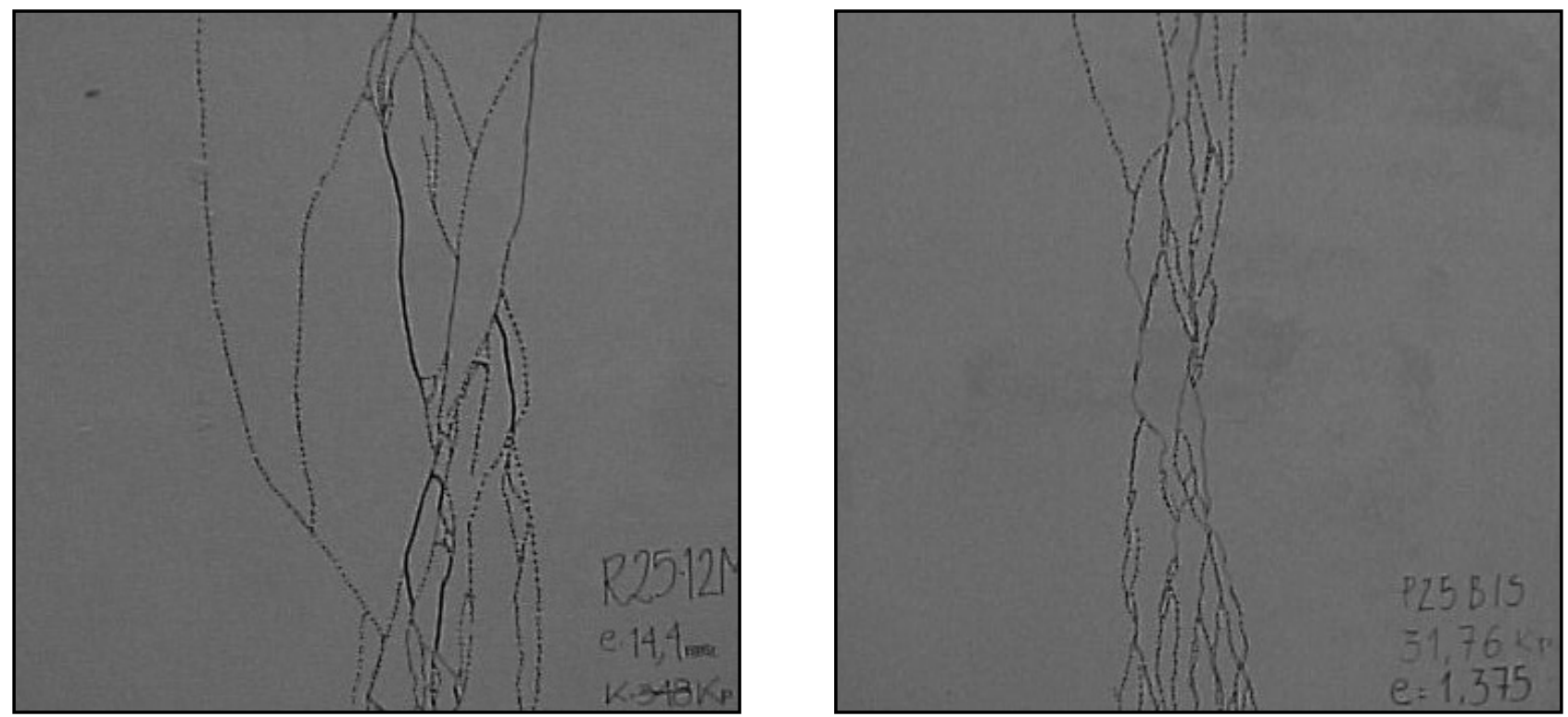

Figura 12. Líneas de rotura en probetas de $60 *-60 * 1$.

Figure 12. Failure lines on $60 * 60 * 1-\mathrm{cm}$ panes. 
matriz con los agregados, de modo análogo a lo observado en las probetas ensayadas de $16 * 4 * 4$. La existencia de varias microfisuras permite que cada una de ellas absorba parte del estado tensional evitando la acumulación de tensiones en un único plano de rotura, con la consiguiente rotura en dos partes de la placa.

Las placas con deformaciones correspondientes 1/30 de la distancia entre apoyos, se han podido volver a utilizar aplicándolas una lechada de escayola y una anulación de la deformación obtenida, no apreciándose defectos visuales en su superficie.

La escayola, con relación 0,7 entre la cantidad de agua / conglomerante, y con adiciones del $2 \%$ en peso (sobre la cantidad de escayola), tanto de poliestireno expandido como de fibras de polipropileno, permite reducir la densidad: en un $50,88 \%$ sobre los valores de una escayola sin ningún tipo de adición y en un $32,88 \%$ con respecto a las placas de yeso laminado (PYL), como aparece reflejado en la Figura 13. matrix and aggregates. With several microfissures present, each could absorb part of the stress state, thereby avoiding specimen fracture due to the accumulation of stress on any single failure plane.

The panes with strain values of $1 / 30$ of the distance between supports could be re-used by applying a plaster grout and eliminating the deformation observed, with no visible surface flaws.

With a water/binder ratio of 0.7 and $2 \%$ additions (by weight of plaster) of both expanded polystyrene and polypropylene fibre, the decline in density found was $50.88 \%$ over the plain plaster value and $32.88 \%$ over the plasterboard pane (PYL) values, as shown in Figure 13.

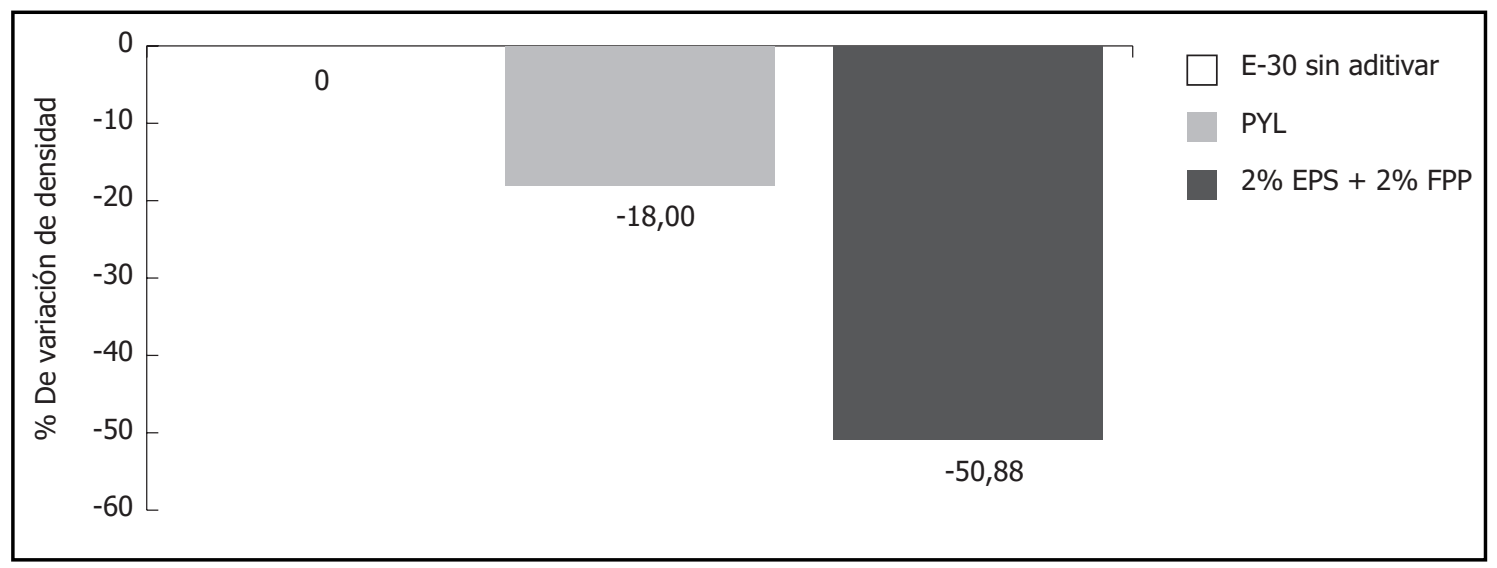

Figura 13. Porcentajes de reducción de peso con respecto a la escayola sin ningún tipo de adición. Figure 13. Weight reduction. Percentage of control value.

En la Figura 14 se refleja el comportamiento del material, ante el ensayo de caída de una bola de acero desde diversas alturas, midiéndose la huella que produce en la superficie de la placa.

Una escayola sin ningún tipo de adición rompe ante una altura de caída de bola de 0,6 m, mientras que la escayola aditivada presenta aparición de fisuraciones a partir de los $6 \mathrm{~m}$ de altura de caída de bola, lo que implica un incremento de resistencia a impacto del $900 \%$.

El material por tanto carece de rotura frágil, que es una característica de la matriz de escayola, apareciendo microfisuras en la superficie, que no producen el colapso del elemento constructivo.
Figure 14 shows material hardness, measured in terms of the indentation on the pane surface caused by the impact of a steel ball dropped from a number of heights.

Plain gypsum plaster panes broke when the ball was dropped from $0.6 \mathrm{~m}$, whereas the aggregate-reinforced plaster merely cracked when the ball was dropped from a height of $6 \mathrm{~m}$ : a 900\% gain in impact resistance.

The material did not, then, undergo the brittle failure characteristic of the plaster matrix, nor did the microfissures that appeared on the surface lead to element collapse. 


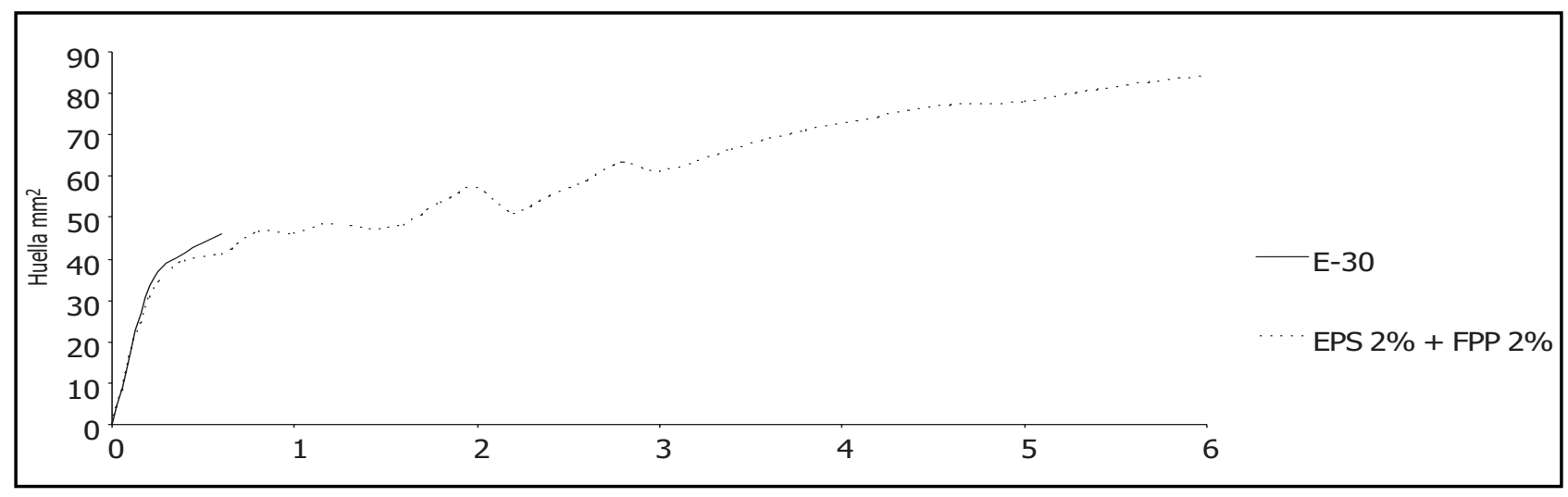

Figura 14. Relación entre la altura de caída de bola y el tamaño de la huella.

Figure 14. Ratio between falling height and size of the indentation.

En relación con el sistema constructivo, estas placas pueden ser utilizadas con perfilerías normalizadas existentes en el mercado de un modo análogo al de las placas de yeso laminado con las siguientes ventajas:

- Este tipo de placas reforzadas con fibras de polipropileno y aligeradas con EPS permite la resolución de todos los tipos de tabiques de distribución interior con un solo tipo de placa, ya que es un material homogéneo con distribución aleatoria de sus agregados. Con la placa de yeso laminado existen 6 tipos normalizados (STD, F, AD, HR, H y M0) dependiendo del tipo de refuerzo laminar superficial que posea (celulosa, velos superficiales de fibra de vidrio, etc.) o de adiciones en masa para disminuir la absorción de agua, necesitando, por tanto, en la definición de un proyecto y en la posterior dirección de obra, una complicación de selección de la placa idónea para cada cerramiento.
These panes can, moreover, be used with the standard profiles available on the market in much the same way as plasterboard, with the following advantages:

- This type of PPF-reinforced and EPS-lightened panes can be used to build all types of partitions with a single type of pane, for it is a uniform material with randomly distributed aggregates. There are six standard types of plasterboard (STD, F, AD, HR, H and MO) depending on the type of surface reinforcement layer (cellulose, fibreglass) or superplasticizing admixture used. This adds to design and site supervision complexity in connection with the selection of the ideal pane for each enclosure.

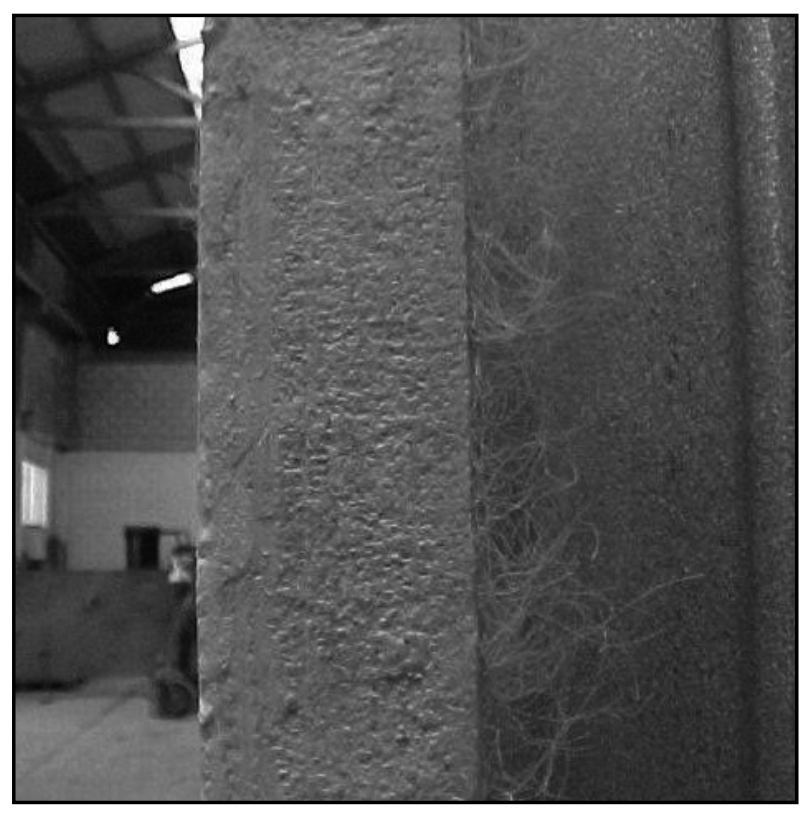

Figura 15. Aspecto de los bordes de las placas. Figure 15. Pane edges. 
- Resolución y simplificación de la problemática de las juntas entre cada una da las placas. Al ser un material homogéneo e isótropo no se necesita usar vendas de unión de las placas entre sí, ya que las fibras situadas en los bordes permiten ese trabajo con la adición del mismo tipo de pasta de escayola con la misma relación de agua yeso que el resto de la placa (Figura 15). En las placas de yeso laminado existen 6 tipos de bordes longitudinales (BC, BB, BA, BSR, BSA y BR) para cada función específica.

Posibilidad de atornillado (Figura 16) y clavado (Figura 17) sin necesidad de elementos de conexión, ya que las fibras existentes en el interior del material colaboran enrollándose en los tornillos, contribuyendo a su enganche. Las placas de yeso laminado no tienen esa posibilidad.

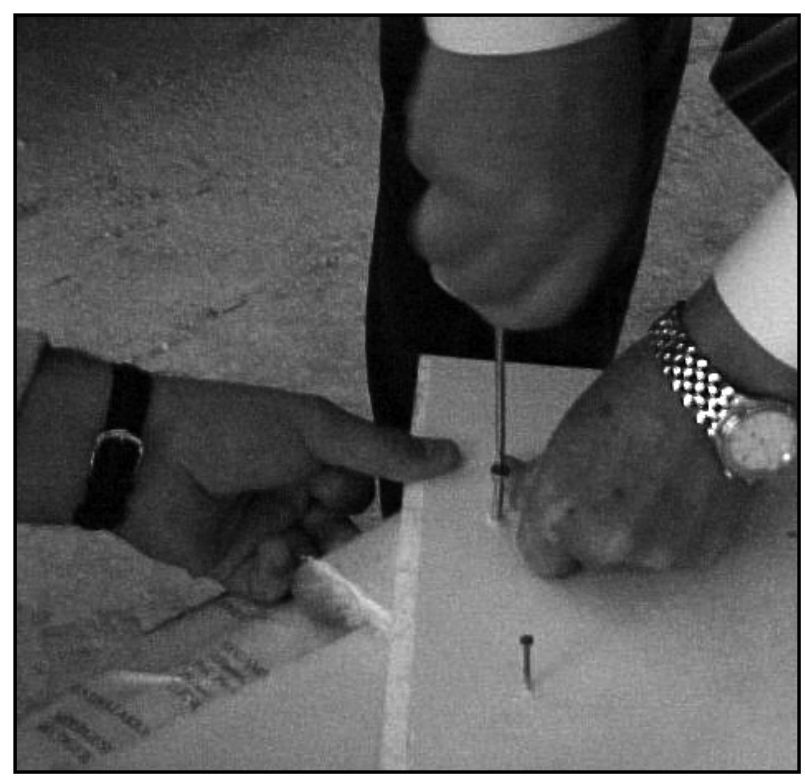

Figura 16. Atornillado de las placas.

Figure 16. Screws in panes.

Las texturas que pueden obtenerse en las placas son análogas a las de cualquier placa realizada con escayola sin ningún tipo de adición, ya que en la interfase entre el desencofrante del molde y el material que confina se producen fenómenos de repulsión de las adiciones de fibras y granulados, de modo que en la superficie de la placa, una vez desmoldada, no aparecen restos apreciables de las adiciones que posee. Figuras 18 y 19.

\section{CONCLUSIONES}

La escayola, con relación $A / Y=0,7$ con adición del $2 \%$ de fibras polipropileno y con el $2 \%$ de granulado de poliestireno expandido (EPS), produce:
- Solution and simplification of inter-pane jointing. Since the material is uniform and isotropic, the plates do not need to be taped together. The fibre around the edges serves this purpose when two panes are joined with the same type of plaster having the same water/plaster ratio as the pane themselves (Figure 15). Six types of edging ( $B C, B B, B A, B S R, B S A$ and $B R$ ) are also needed for standard plasterboard, depending on the specific function.

Ability to use screws (Figure 16) or nails (Figure 17) on panes with no need for attachment elements, for the fibre inside the material wraps around the screws, securing them more tightly. Plasterboard does not feature this possibility.

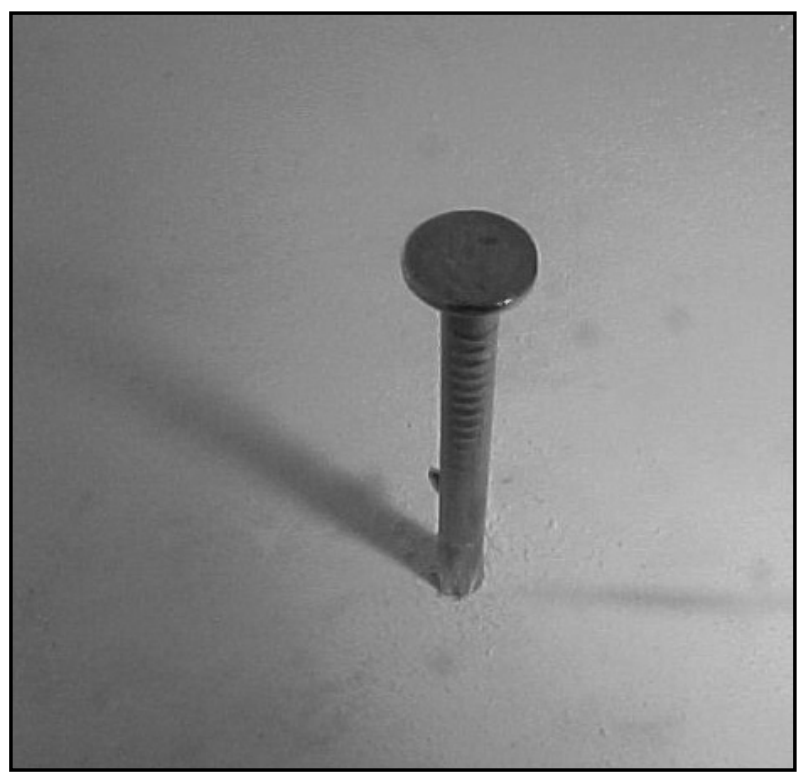

Figura 17. Clavado sin fisuración de las placas. Figure 7. Nails in uncracked panes.

comparable to those of any plain gypsum plaster product, for the fibres and beads generate repulsion at the interface between the mould and the material. As a result, no trace of the aggregates appears on the demoulded elements. Figures 18 and 19.

\section{CONCLUSIONS}

Gypsum plaster with a W/P ratio of 0.7 and containing $2 \%$ polypropylene fibre and $2 \%$ expanded polystyrene (EPS) beads generates a product characterized by: 


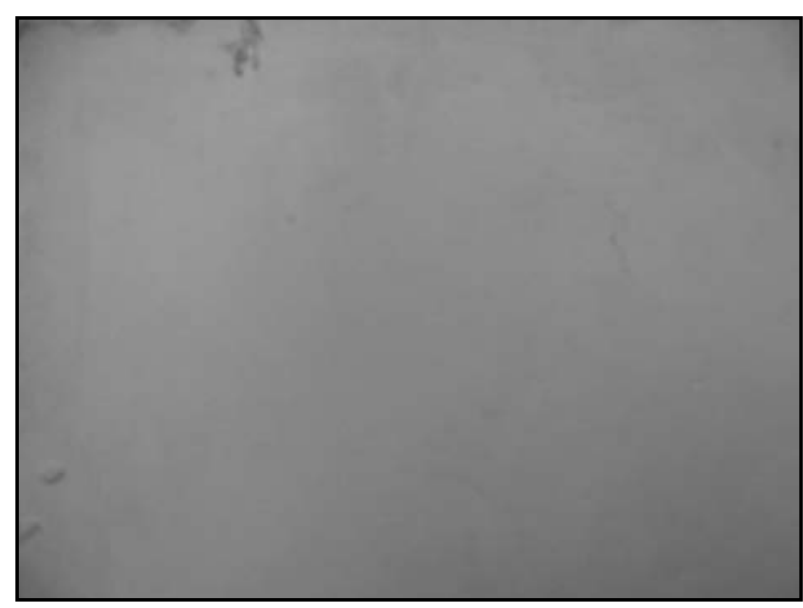

Figura 18. Placa reforzada con fibras de polipropileno. Figure 18. Polypropylene fibre-reinforced pane.

- Ausencia de rotura frágil. Una vez fisurada la placa no se produce caída de material. El material fisurado puede ser reparado.

- Incrementa la resistencia a flexión de las placas en un $22,77 \%$ con respecto a una placa de escayola sin ningún tipo de adición.

- Disminución de peso. Reduce la densidad: en un $50,88 \%$ sobre los valores de una escayola sin ningún tipo de adición y en un $32,88 \%$ con respecto a las placas de yeso laminado (PYL).

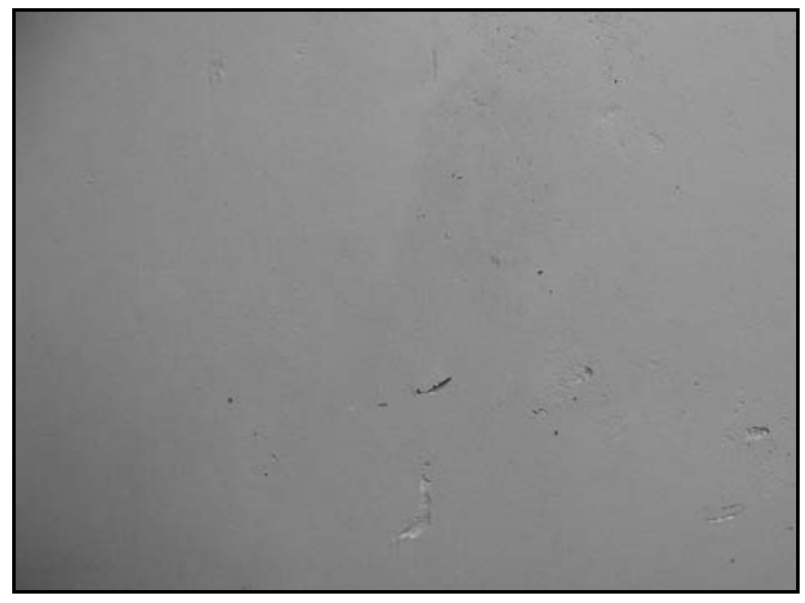

Figura 19. Placa reforzada con fibras de polipropileno y granulado de EPS.

Figure 19. Polypropylene fibre-reinforced, EPS-lightened pane.

- The absence of brittle failure. Cracking does not lead to flaking or detachment. Cracked material can be repaired.

- A bending strength $22.77 \%$ higher than in plain plaster with no added aggregate.

- Lighter weight. Reduced density: 50,88\% less than in plain plaster and $32.88 \%$ less than in plasterboard panes (PYL).

\section{BIBLIOGRAFÍA / BIBLIOGRAPHY}

(1) García Santos, A.: "Los Plásticos en la Construcción I y II". Madrid. Cuadernos del Instituto Juan Herrera, Escuela Técnica Superior de Arquitectura (2001).

(2) Rincón, J. M.; Romero, M.; Hernández-Crespo; Talero; M., R. y García Santos A.: "Microestructura de un material compuesto basado en una matriz de cemento reforzado con fibras de polipropileno". Mater. Construcc. 54, no 274, CSIC (abril/mayo/junio 2004 ), pp. 73-82. (3) L. de Villanueva Domínguez y A. García Santos. "Manual del Yeso", ATEDY (Asociación Técnica y Empresarial del Yeso). Ed. Dossat, Madrid, 2000.

(4) B.A. Sanders, ASTM "Short Fiber Reinforced Composite Materials", 1982.

(5) A. García Santos. "Comportamiento mecánico del yeso reforzado con polímeros sintéticos". Tesis Doctoral, ETSAM.

(6) A. García Santos. "Comportamiento mecánico de yeso reforzado con polímeros sintéticos". Informes de la Construcción, IETcc. Vol. 40, no 397, pp. 67-89, septiembre/octubre 1988.

(7) González Madariaga F.J., Lloveras Macia J.: "Algunos resultados de los trabajos de experimentación acerca de la reutilización de espumas de poliestireno expandido". VIII International Congress on Project Engineering. Bilbao. 2004.

(8) K. Miled, R. Le Roy, K. Sab, C. Boulay. "Compressive behaviour of an idealized EPS lightweight concrete: size e.ects and failure mode". Mechanics of Materials 36 (2004) 1031-1046. doi:10.1016/j.mechmat.2003.08.004

(9) A. Laukaitis, R. Zurauskas, J. Keriené. "The effect of foam polystyrene granules on cement composite properties". Cement \& Concrete Composites, 27 (2005) 41-47. doi:10.1016/j.cemconcomp.2003.09.004

(10) N.W. Choi, Y. Ohama. "Development and testing of polystyrene mortars using waste EPS solution-based binders". Construction and Building Materials, 18 (2004) 235-241. doi:10.1016/j.conbuildmat.2004.01.003

(11) A. Beltramone, F. Alejandro García Cruz, A. García Santos. "Modificaciones de las propiedades superficiales en el hormigón visto, por la utilización de diferentes tipos de desencofrantes y aditivos plásticos". Mater. Construcc. Vol. 53, no 270, pp. 71-78. Abril/mayo/junio 2003. CSIC.

(12) A. García Santos. "Aplicaciones constructivas de un material compuesto de escayola y fibras naturales de Typha Latifolia". Mater. Construcc. Vol. 54, no 273, pp. 73-77. enero/febrero/marzo 2004. CSIC. 
(13) A. García Santos. "Caracterización de compuestos de escayola reforzados, en relación con el tipo de refuerzo y la relación A/Y". Informes de la Construcción, IETcc. Vol. 56, no 493 (octubre 2004).

(14) A. García Santos, J. M. Rincón, M.Romero y R. Talero. "Characterization under ESEM, FESEM and mechanical testing of a polypropylene fibered cement composite". Construction and Building Materials. Vol. 19 (2005), pp. 396-403. doi:10.1016/j.conbuildmat.2004.07.023 